Economics Development Analysis Journal 6(1)(2017)

\title{
Analysis of Effect of Capital Inflow Volatility and Macroeconomic Variables on Rupiah Exchange Rate
}

\author{
Adnan Muhammad Feisal ${ }^{1 凶}$, Lesta Karolina Br. Sebayang ${ }^{2}$
}

Economics Development Department, Economics Faculty, Universitas Negeri Semarang

\begin{tabular}{|c|c|}
\hline Article Info & Abstract \\
\hline $\begin{array}{l}\text { Article History: } \\
\text { Received October } 2017 \\
\text { Accepted December } 2017 \\
\text { Published February } 2017\end{array}$ & $\begin{array}{l}\text { The purpose of this research is to measure the effect of the capital inflow volatility on the rupiah } \\
\text { exchange rate, to measure the effect of macroeconomic variables on the rupiah exchange rate, and } \\
\text { to measure the response of capital inflow shocks and macroeconomic variables on the rupiah } \\
\text { exchange rate. The data used is in the form of quarterly time series data from 2002:4-2014:4, which } \\
\text { is derived from the data of Bank Indonesia. The model used in this research is the Vector Error }\end{array}$ \\
\hline $\begin{array}{l}\text { Keywords: } \\
\text { Capital Inflow; Rupiah } \\
\text { Exchange Rate; } \\
\text { Macroeconomic Variables. }\end{array}$ & $\begin{array}{l}\text { Correction Model (VECM). The results show that: (1) In the short-term capital inflow has the } \\
\text { positive and significant effect on the rupiah exchange rate, while in the long-term it does not have } \\
\text { the significant effect on the rupiah exchange rate. (2) Macroeconomic variable that has the positive } \\
\text { and significant effect on the rupiah exchange rate in the short-term is the capital inflow variable. In } \\
\text { the long-term the macroeconomic variable that has the positive and significant effect on the rupiah } \\
\text { exchange rate is the foreign exchange reserves variable. (3) Results of IRF, the response of the rupiah } \\
\text { exchange rate of the capital inflow shocks indicates that an increase in capital inflow has effect on } \\
\text { the strengthening of the rupiah exchange rate. The shocks on the foreign reserve variable have the } \\
\text { positive effect on the rupiah exchange rate, and the shocks on the inflation variable have the negative } \\
\text { effect on the rupiah exchange rate. }\end{array}$ \\
\hline
\end{tabular}

Journal's Room, L Building, FE UNNES Sekaran Gunungpati

Semarang 50229, Indonesia

E-mail: adnanfaishall@gmail.com 


\section{INTRODUCTION}

Globalization and economic liberalization have brought a very rapid and widespread renewal for the economy, both in the domestic and the international level. The more integrated the various aspects of economy in a country are with the world economy lead to an increase in the flow of trade in goods and money and capital among the countries. The presence of foreign capital inflows is indirectly can move the development of the financial sector to grow more advanced and ultimately to be going to accelerate the economic growth. Relating to the heavy flow of foreign capital, it will affect the stability of the Indonesian economy from the external aspects that is the fluctuation of the rupiah exchange rate at any time.

Indonesia is a large country and a developing country that requires substantial funds to implement the national development. The huge funding is needed for implementing the development in order to make efforts to equalize other countries, especially the developed countries, both in regional and global regions. Domestic funds (domestic investment) are perceived to be inadequate for the development so that the government tries to withdraw the funds from inside and outside the country (Lumbanraja, 2006: 61). The presence of foreign capital inflows is indirectly can move the development of the financial sector to grow more advanced and ultimately to be going to trigger the economic growth.

Table 1. Amount of Capital Inflow in Indonesia in 2002:1 - 2014:4

\begin{tabular}{llll}
\hline No & Quarterly & Year & $\begin{array}{l}\text { Capital } \\
\text { Inflow }\end{array}$ \\
\hline 1 & 1 & 2002 & 1,266 \\
2 & 2 & 2002 & 739 \\
3 & 3 & 2002 & 639 \\
4 & 4 & 2002 & 172 \\
5 & 1 & 2003 & 595 \\
6 & 2 & 2003 & 1,163 \\
7 & 3 & 2003 & 324 \\
8 & 4 & 2003 & 1,169 \\
9 & 1 & 2004 & 1,239 \\
10 & 2 & 2004 & 297 \\
\hline
\end{tabular}

\begin{tabular}{|c|c|c|c|}
\hline 11 & 3 & 2004 & 908 \\
\hline 12 & 4 & 2004 & 1,716 \\
\hline 13 & 1 & 2005 & 1,453 \\
\hline 14 & 2 & 2005 & 4,402 \\
\hline 15 & 3 & 2005 & 3,000 \\
\hline 16 & 4 & 2005 & 3,676 \\
\hline 17 & 1 & 2006 & 5,061 \\
\hline 18 & 2 & 2006 & 2,194 \\
\hline 19 & 3 & 2006 & 1,501 \\
\hline 20 & 4 & 2006 & 3,136 \\
\hline 21 & 1 & 2007 & 3,528 \\
\hline 22 & 2 & 2007 & 4,803 \\
\hline 23 & 3 & 2007 & 2,654 \\
\hline 24 & 4 & 2007 & 1,467 \\
\hline 25 & 1 & 2008 & 4,344 \\
\hline 26 & 2 & 2008 & 5,821 \\
\hline 27 & 3 & 2008 & 3,462 \\
\hline 28 & 4 & 2008 & 6,314 \\
\hline 29 & 1 & 2009 & 3,854 \\
\hline 30 & 2 & 2009 & 3,340 \\
\hline 31 & 3 & 2009 & 3,959 \\
\hline 32 & 4 & 2009 & 4,061 \\
\hline 33 & 1 & 2010 & 9,070 \\
\hline 34 & 2 & 2010 & 4,369 \\
\hline 35 & 3 & 2010 & 7,392 \\
\hline 36 & 4 & 2010 & 5,742 \\
\hline 37 & 1 & 2011 & 8,636 \\
\hline 38 & 2 & 2011 & 9,970 \\
\hline 39 & 3 & 2011 & 8,119 \\
\hline 40 & 4 & 2011 & 5,854 \\
\hline 41 & 1 & 2012 & 7,110 \\
\hline 42 & 2 & 2012 & 7,168 \\
\hline 43 & 3 & 2012 & 8,446 \\
\hline 44 & 4 & 2012 & 5,887 \\
\hline 45 & 1 & 2013 & 6,602 \\
\hline 46 & 2 & 2013 & 7,947 \\
\hline 47 & 3 & 2013 & 7,816 \\
\hline 48 & 4 & 2013 & 6,283 \\
\hline 49 & 1 & 2014 & 13,763 \\
\hline 50 & 2 & 2014 & 13,230 \\
\hline 51 & 3 & 2014 & 15,051 \\
\hline 52 & 4 & 2014 & 7,052 \\
\hline \multicolumn{4}{|c|}{ Source: Bank Indonesia, 2014} \\
\hline \multicolumn{4}{|c|}{$\begin{array}{l}\text { The capital inflow to the developing } \\
\text { countries is caused by several factors as follows: } \\
\text { the high level of financial integration along with } \\
\text { the rapid development of technology, especially } \\
\text { the information and communication technology, } \\
\text { which plays a big role in accelerating the } \\
\text { increased mobility of capital inflow; the } \\
\text { infrastructure development accompanied by }\end{array}$} \\
\hline
\end{tabular}


liberalization such as the elimination of repatriation barriers, the reduction of barriers to participation and foreign ownership (Indawan F, 2013: 32).

Based on the time of observation conducted since 2002: 1 - 2014: 4, the capital inflow to Indonesia fluctuated in its short and long term. In 2008 the capital inflow to Indonesia reached 19 million US Dollar. That number increased seven million US Dollar that in 2007 amounted to 12 million US Dollar. This was motivated by the increase in domestic economic activity, the improved investment climate, and the improved investor perceptions of the financial resilience of the country after the fuel price increase.

In 2014, the overall performance of the capital and financial transactions recorded a significant increase, even reached the highest level since 2010. Although at the fourth curve in 2014 it decreased due to the investor concerns related to The Fed's plan to accelerate the interest rate increase, it did not too significantly affect as a whole in 2014, which recorded the income of capital inflow of 49 million US Dollar. It increased almost 2-fold when compared with what occurred in 2013 that amounted to 28 million US Dollars.

The capital inflow to a country will affect the exchange rate of the country. The more increasing the amount is will appreciate the exchange rate of the country. However, it did not occur in Indonesia in some periods. The increased capital inflow to Indonesia actually depreciates even the rupiah exchange rate. Based on the description above, some research questions can be formulated as follows:

1. What is the effect of capital inflow volatility on the rupiah exchange rate?

2. What is the effect of macroeconomic variables (exports, foreign exchange reserves, and inflation) on the rupiah exchange rate?

3. How does the shock response or the shock of capital inflow and macroeconomic variables (exports, foreign exchange reserves, and inflation) to the rupiah exchange rate?

\section{RESEARCH METHOD}

Type and Design of Research, this research is a quantitative descriptive research, because it uses quantitative data and applies the existing theory. The type of data used in this research is secondary data that is obtained from several sources those are: Bank Indonesia (BI), Central Bureau of Statistics (BPS), and literature study through journals, articles and papers, and other agencies. The secondary data used are systematically recorded data in the form of time series data that is quarterly data covering the data from the first quarter (Q1) in 2002 to the fourth quarter (Q4) in 2014.

Data Analysis Method, this research uses quantitative analysis, which is a form of analysis that uses secondary data and is grouped in time series.

The method of analysis used in this research consists of seven stages those are Test Stationary Data, Optimal Lag Test, Cointegration Test, Granger Causality Test, VECM, IRF, and FEVD. The equation to be used in this research is

$\Delta \mathrm{Ln}_{-} \mathrm{ERT}_{\mathrm{t}} \quad=\mathrm{a}_{0}+\mathrm{a}_{11} \Delta \mathrm{Ln} \mathrm{LRT}_{\mathrm{t}-\mathrm{i}}+$ $\mathrm{a}_{12} \Delta \mathrm{Ln} \_\mathrm{CIF}_{\mathrm{t}-\mathrm{i}}+\mathrm{a}_{13} \Delta \mathrm{Ln} \_\mathrm{EKS}_{\mathrm{t}-\mathrm{i}}+\mathrm{a}_{14} \Delta \mathrm{Ln} \_\mathrm{CDV}_{\mathrm{t}-\mathrm{i}}$ $+\mathrm{a}_{15} \Delta \mathrm{INF}_{\mathrm{t}-\mathrm{i}}+\varepsilon$

\section{RESULT AND DISCUSSION}

Data Stationarity Test, this research uses Augmented Dickey-Fuller (ADF) to test the data stationarity. In the ADF test, if the ADF value is smaller than McKinnon Critical Value, it can be concluded that the data is stationary. If based on the ADF test it is not stationary, the solution is by the process of differentiation. The unit root test of each variable in the research model is based on the test at the level. The test results can be seen in Table 2 .

Optimal Lag Test, Optimum lag determination is an important level because the independent variable used is the lag of the dependent variable and also the independent variable. This is important because it is related to the accuracy of the information that will be produced by the estimation of VECM model. 
Table 3. Results of Optimal Lag Test

\begin{tabular}{lllll}
\hline LR & FPE & AIC & SC & HQ \\
\hline NA & $4.5 \times 102$ & 80.167 & 80.3624 & 80.2412 \\
350,844 & 8 & 56 & 7 & 2 \\
1 & 25 & $79.85 \times 10$ & 74.0252 & 73.2977 \\
53,1432 & $2.11 \times 10$ & 72.461 & 74.6052 & 73.2714 \\
$5^{*}$ & $25^{*}$ & 15 & 4 & $1^{*}$ \\
\hline
\end{tabular}

Source: Processing result of Eviews 8

Description: sign $\left({ }^{*}\right)$ is optimal lag

The results show that the optimal lag for the variables to be estimated is the second lag.

Co-integration Test, the co-integration test aims to find out the long-term equilibrium relationship between the capital inflow and macroeconomic variables with the rupiah exchange rate in Indonesia within the period of 2002:1 - 2014:4.

Table 4. Results of Co-integration

\begin{tabular}{|c|c|c|c|c|c|}
\hline Ho & $\mathrm{R}=0$ & $\mathrm{R}<=1$ & $\begin{array}{l}\mathrm{R}<= \\
2\end{array}$ & $\mathrm{R}<=3$ & $\begin{array}{l}\mathrm{R}< \\
=4\end{array}$ \\
\hline H1 & $\begin{array}{l}\mathrm{R}>= \\
1\end{array}$ & $\mathrm{R}>=2$ & $\begin{array}{l}\mathrm{R}>= \\
3\end{array}$ & $\mathrm{R}>=4$ & $\begin{array}{l}\mathrm{R}> \\
=5\end{array}$ \\
\hline Trace & 76.4 & 33.51 & 1156 & 4.914 & 0.1 \\
\hline Statisti & 9417 & 555 & 048 & 135 & $\begin{array}{l}874 \\
24\end{array}$ \\
\hline Critical & 69.8 & 47.85 & 29.7 & 15.49 & 3.8 \\
\hline $\begin{array}{l}\text { Value } \\
5 \%\end{array}$ & 1889 & 613 & 9707 & 471 & $\begin{array}{l}414 \\
66\end{array}$ \\
\hline
\end{tabular}

Source: Processing results of Eviews 8

Johansen's co-integration test results using a five percent significance level show that there are five co-integrated equations. It can be known because the trace statistic value is greater than the critical value of five percent.

Granger Causality Test, the Granger causality test is performed to see the causal relationship (causality) among the variables presented in the model.

From the test in Table 4.4., the results show that there is one way relationship between CDV variable with $\mathrm{CIF}$ variable, $\mathrm{CDV}$ variable with ERT variable, $C D V$ variable with EKS variable, and EKS variable with CIF variable.

VECM Estimation Results, having found the co-integration relationship among the research variables, the next step is to form the
VECM model. The estimation result of VECM for both long and short terms can be seen in table 6.

The result of estimation performed shows that in the long term, the foreign exchange reserve variable significantly has the positive effect on the rupiah exchange rate and the export variable significantly has the negative effect on the rupiah exchange rate. While in the short term, the capital inflow variable significantly has the positive effect on the exchange rate and the foreign exchange reserve variable significantly has the negative effect on the exchange rate.

Impulse Response Function (IRF) is used to see the contemporary effect of a variable on other variables. In this research, IRF basically consists of four stages those are to see the effect of variables of capital inflow, foreign exchange, inflation, and export on the rupiah exchange rate.

The exchange rate response due to the shocks of one standard deviation of the capital inflow causes the exchange rate fluctuations. Figure 4.1 shows that the shocks of the capital inflow of one standard deviation in the first period have not been responded yet by the exchange rate. It is responded positively in the second period and causes the exchange rate depreciation of 13.27584 of standard deviation. However, the effect of the capital inflow shocks is also responded negatively, or it can be said that there is a decline in the exchange rate (appreciation) in the third period of -20.00377 . Then it is responded positively again in the $14^{\text {th }}$ period to the $19^{\text {th }}$ period and in the $33^{\text {rd }}$ period to the $35^{\text {th }}$ period. After that it is negatively responded again to the end of the period.

The shocks of one standard deviation from inflation have not been responded yet by the exchange rate at the beginning of the period, which means that the inflation shocks do not necessarily cause the appreciation of the rupiah exchange rate. The negative response occurs in the second period of -120.1618 of standard deviation. In the third period until the end of the period, the inflation variable is responded negatively by the exchange rate. The biggest response occurred in the eleventh period of 98.05641 of standard deviation. 
Table 5. Results of Granger Causality Test

\begin{tabular}{llllll}
\hline & \multicolumn{5}{c}{ Probability is not Granger Cause } \\
\cline { 2 - 6 } Variables & CIF & ERT & INF & CDV & EKS \\
CIF & & 0.1067 & 0.5835 & 0.1292 & 0.1870 \\
ERT & 0.4491 & & 0.9930 & 0.3591 & 0.8386 \\
INF & 0.3185 & 0.8297 & & 0.7880 & 0.6608 \\
CDV & 0.0474 & 0.0541 & 0.1856 & & 0.0961 \\
EKS & 0.0030 & 0.1505 & 0.5025 & 0.9677 & \\
\hline
\end{tabular}

Source: Processing result of Eviews

Table 6. Estimation Result of VECM

\begin{tabular}{llll}
\hline Variables & Coefficient & Std. Error & T-Statistic \\
Short Term & & & \\
CointEq1 & -0.233375 & 0.07015 & $-3.32684^{*}$ \\
D(ERT(-2)) & -0.562453 & 0.22252 & $-2.52764^{*}$ \\
D(CIF(-2)) & 0.249069 & 0.06626 & $3.75898^{*}$ \\
D(EKS(-2)) & -0.070353 & 0.09986 & -0.70449 \\
D(CDV(-2)) & -0.048255 & 0.02161 & $-2.23312^{*}$ \\
D(INFLASI(-2)) & 47.35424 & 37.0165 & 1.27927 \\
Long Term & & & \\
DLn_CIF(-1) & 0.377775 & 0.28968 & 1.30410 \\
DLn_EKS(-1) & -0.729761 & 0.13333 & $-5.47330^{*}$ \\
DLn_CDV(-1) & 0.056010 & 0.02386 & $2.34728^{*}$ \\
DINFLASI(-1) & 243.8645 & 99.8549 & 1.44219 \\
\hline
\end{tabular}

Source: Processing result of Eviews 8

The response of the exchange rate variable to the exchange rate variable shocks has not shown yet the response at the beginning of the period and it is responded positively starting from the second period to the end of the period that is the $52^{\text {nd }}$ period. The highest positive response occurs in the fifth period of 259.8227 of standard deviation.

The foreign exchange reserve variable in the first period of exchange rate has not responded yet to the shock. The new response is

Response of DRUPIAH_NILA__TUKAR to DJUTA_USD_CAPTTAL_INFLOW

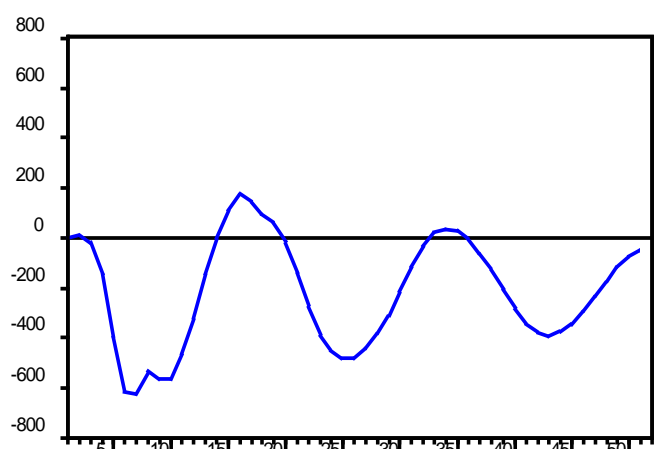

shown in the second period with a negative response of -173.5900 of standard deviation. The positive response of the exchange rate variable to the foreign exchange reserve variable shocks occurs in the ninth period to the $18^{\text {th }}$ period then in the 26th period up to the 36th period and in the $44^{\text {th }}$ period until the end of the $52^{\text {nd }}$ period. The largest positive response occurs in the thirteenth period of 365.3084 of standard deviation and the largest negative response occurred in the third period of 270.9700 of standard deviation.

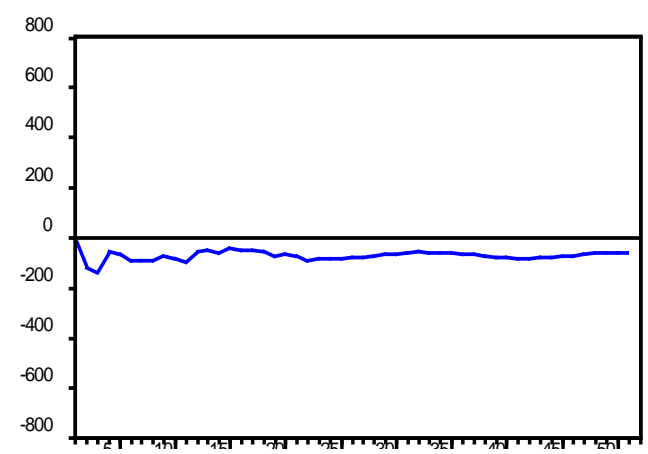


Response of DRUPIAH NILA TUKAR to DJUTA USD EKSPOR

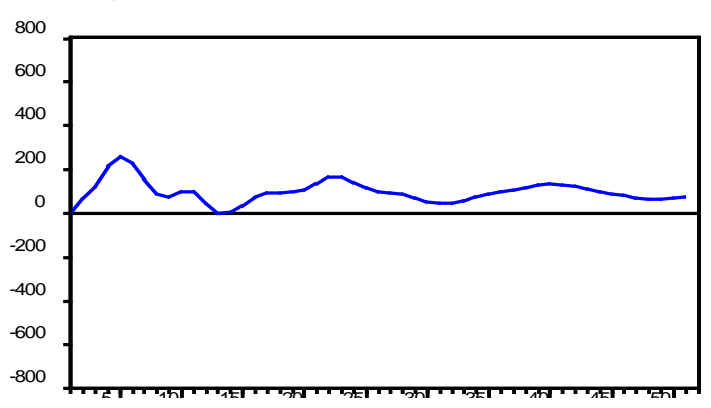

Response of DRUPIAH NILA TUKAR to DCADANGAN DEVISA

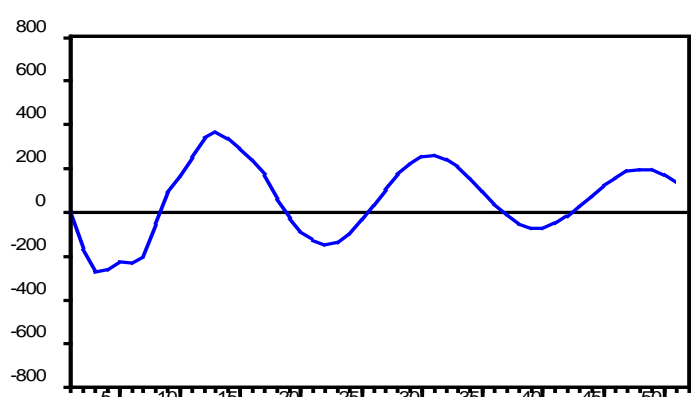

Figure 1. Result of IRF

Source: Processing Result of Eviews 8

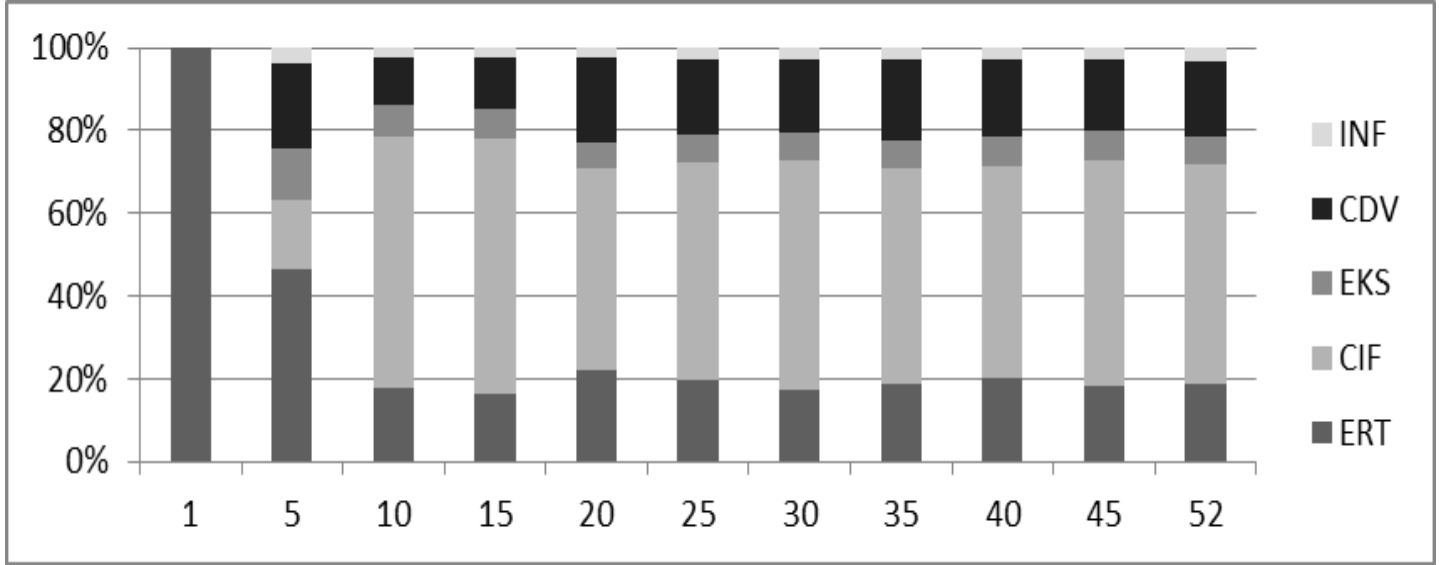

Figure 2. Result of FEVD

Forecast Error Variance Decomposition (FEVD , Variance decomposition aims to measure how large the error variance of a variable is described in the variable shock itself or the other variables.

FEVD result indicates that the dominant exchange rate variance is described in the variable shock itself at the beginning of the period. Then starting from the tenth to the end of the dominant period it is described by the capital inflow variable. The effect of a large exchange rate on itself can be interpreted that there are speculation behaviors of the money market participants to the depreciation and appreciation of the rupiah exchange that affect the movement of the rupiah exchange rate. In the first period the exchange rate affects itself by 100 percent and decreases to 46.40879 percent by the end of the fifth period. Then there is the capital inflow variable that affects the exchange rate of 16.60952 percent in the fifth period and continues to increase until the end of period reaching 52.83226 percent.

The foreign exchange reserves also have a share that affects the rupiah exchange rate besides the capital inflow variable. The foreign exchange reserves affect the exchange rate of 20.65627 percent at the end of the fifth period and continue to increase reaching 21.42399 percent at the end of the fifteenth period. After that, it continues to decline until the end of the period of 18.23774 percent. Other macroeconomic variables such as inflation and exports only have the little effect on the rupiah exchange rate. 


\section{CONCLUSION}

- Based on the results of the analysis and discussion that has been conducted, it can be concluded as follows: The capital inflow in the short term has the positive and significant effect on the rupiah exchange rate while in the long term the capital inflow does not have the significant effect on the rupiah exchange rate, the macroeconomic variable in the short term that has the positive and significant effect on the rupiah exchange rate is the capital inflow variable, while the macroeconomic variable in the short term that has the negative and significant effect on the rupiah exchange rate is the foreign exchange reserve variable. In the long term the macroeconomic variable that has the positive and significant effect on the rupiah exchange rate is the foreign exchange reserve variable, while the macroeconomic variable in the long term that has the negative and significant effect on the rupiah exchange rate is the export variable, based on the IRF result, the rupiah exchange rate response to the capital inflow shocks shows that an increase in the capital inflow affects the strengthening of the rupiah exchange rate, while the IRF result in the macroeconomic variables indicating that the shock on the export variable gives the positive effect on the rupiah exchange rate, the shock on the foreign exchange reserve variable gives the positive effect on the rupiah exchange rate, and the shock on the inflation variable gives the negative effect on the rupiah exchange rate.

\section{REFERENCES}

Carp, Lenuta. (2014). Financial Globalization and capital flows volatility effects on economic growth. Procedia Economics and Finance. Vol 15 Page 350-356.

Dion, Richard dkk. (2005). Exports, Imports and the Appreciation of Canadian Dollar. Bank Of Canada.

Djulius, Horas dan Yudi Nurdiansyah. (2014). Keseimbangan Jangka Panjang dan Jangka Pendek Nilai Tukar Rupiah terhadap Dollar Amerika. Jurnal Trikonomika. Universitas Pasundan Bandung.
Hossain, A. dan Chowdhury, A. (1998). Open Economy Microeconomics for Developing Countries. Massachussets: Edward Elgar.

Indawan, F. dkk. (2013). Capital Flows Di Indonesia: Perilaku, Peran, dan Optimalitas Penggunaannya bagi Perekonomian. Buletin Ekonomi dan Perbankan: BI, Jakarta.

Lumbanraja, T. G. (2006). Analisis Pengaruh Foreign Direct Investment (FDI) terhadap Nilai Tukar Rupiah. Skripsi. Bogor: Fakultas Ekonomi dan Manajemen, IPB.

Mankiw, N. Gregory. (2006). Teori Makro ekonomi Edisi ke-5. Jakarta: Erlangga.

$\mathrm{Ng}$, Angela. (2000). Volatility spillover effects from Japan and the US to the Pacific-Basin. Journal of International Money and Finance. Vol. 19 (2) pages 207-233.

Nopirin. (2012). Ekonomi Moneter: Buku ke-2. Yogyakarta: BPFE

Oskooee, Mohsen Bahmani., Hegerty, Scott W. (2007) Exchange rate volatility and trade flows: a review article. Journal of Economic Studies. Vol. 34 (3) page 211-255.

Rehman, Hafeez. dkk. (2010). Impact of FDI Inflows on Equilibrium Real Exchange Rate of Pakistan. Journal of South Asian Studies

Safitriani, Suci (2014). Perdagangan Internasional dan Foreign Direct Investment di Indonesia. Jakarta: Buletin Ilmiah Litbang Perdagangan Salvatore, Dominick. (1997). Ekonomi Internasional Edisi Ketiga. Jakarta: Erlangga.

Tambunan, Tulus. (2001). Perdagangan Internasional dan Neraca Pembayaran: Teori dan Temuan Empiris. Jakarta: Pustaka LPJES Indonesia.

Yuliyanti, .... (2014). Pengaruh Jumlah Uang Beredar (M2), Tingkat Suku Bunga Sbi, Impor, Dan Cadangan Devisa Terhadap Nilai Tukar Rupiah / Dolar Amerika Tahun 2001 - 2013. Economics Development Analysis Journal, 3(2). doi:10.15294/edaj.v3i2.3834 